Journal of Humanities and Social Sciences Studies (JHSSS)

ISSN: 2663-7197

DOI: 10.32996/jhsss

Journal Homepage: www.al-kindipublisher.com/index.php/jhsss

\title{
On Psychological Capital Affects Organizational Citizenship Behavior Through Affective Commitment
}

\author{
Irvandi Gustari ${ }^{1}$ and W. Widodo ${ }^{2} \square$ \\ ${ }^{1}$ Indonesia Lecturer in Doctoral Program in Economics, Postgraduate School, Pancasila University, Jakarta, Indonesia \\ ${ }^{2}$ Social Science Education Department, Postgraduate Faculty, Universitas Indraprasta PGRI, Jakarta,
}

$\square$ Corresponding Author: W. Widodo, E-mail: widmag@gmail.com, Orcid ID: https://orcid.org/0000-0002-4564-2694

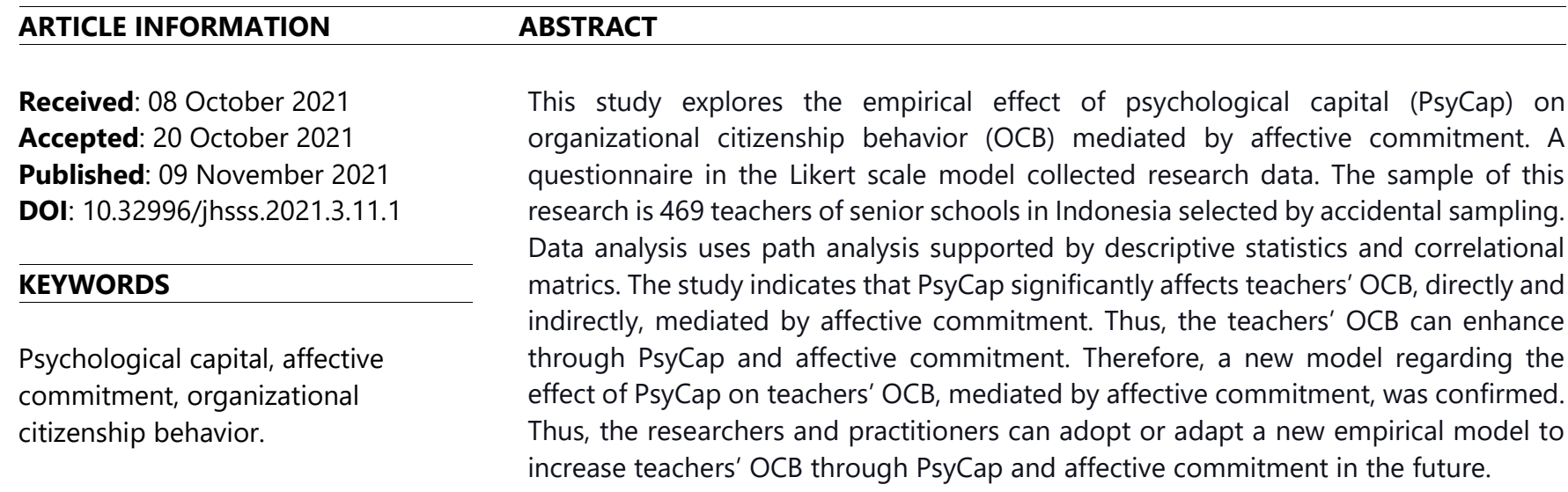

\section{Introduction}

The Covid-19 pandemic has hit the world since the beginning of 2020 and has forced organizations in the world to make extrarole efforts in order to survive. It is not only profit-oriented business organizations that go the extra mile, but also non-profit organizations, such as educational organizations. School organizations, for example, are faced with the fact that they must keep social distancing so that it is not possible to carry out face-to-face learning. This fact requires schools to be forced to do online learning without any preparation. Consequently, teachers face a very difficult reality, which is conducting online learning without the support of adequate information technology facilities and internet networks, with curriculum and subject matter that have not been adapted to the conditions of the pandemic. In this abnormal condition, extra-role behavior is needed, which is commonly known as OCB. In an educational context, OCB influences teachers' innovative behavior (Widodo \& Gustari, 2020) and lecturers' job performance (Gustari \& Widodo, 2020), which is very much needed in abnormal conditions. Other studies in various fields also indicated OCB affects employees' productivity (Barsulai, Makopondo, \& Fwaya, 2019) and performance (Hermawan et al., 2020; Udin \& Yuniawan, 2020), and then implicate to organizational performance (Notanubun, 2020). Hence, in the school context, urgent to investigate teachers' OCB since the Covid-19 pandemic, especially from PsiCap and affective commitment perspective.

OCB is employee behavior beyond the call of duty that exceeds formal job duties, such as cooperation and helpfulness to others that support the organization's social and psychological context, but is often necessary for organizational survival (McShane \& Von Glinow, 2020). According to Schultz and Schultz (2016), OCB includes taking on additional assignments, voluntary assisting other people at work, keeping up with the developments in ones' field or profession, following company rules even when no one is looking, promoting and protecting the organization, and keeping a positive attitude and tolerating inconveniences at work. According to Organ et al. (2006), OCB can measure through five indicators: altruism, conscientiousness, sportsmanship, courtesy, and civic virtue.

\subsection{Psycap and OCB}

Copyright: (C) 2021 the Author(s). This article is an open access article distributed under the terms and conditions of the Creative Commons Attribution (CC-BY) 4.0 license (https://creativecommons.org/licenses/by/4.0/). Published by Al-Kindi Centre for Research and Development, London, United Kingdom. 
Studies regarding PsyCap are increasingly massive because Psycap has contributed to individuals' life and career. Scholars claimed that PsyCap influences performance (e.g., Imran \& Shahnawaz, 2020; Rodríguez-Cifuentes et al., 2020; Alias et al., 2020, Ali et al., 2021). Moreover, PsyCap has significantly affected career outcomes (Baluku et al., 2021), innovative behavior (Slatten et al., 2020; Wang, Chen, \& Zhu, 2020), and job satisfaction (Burhanuddin et al., 2019). Moreover, PsyCap reduces anxiety, depression, and stress (Rodrigues et al., 2017). In the academic context, Psycap is related to academic performance (Carmona-Halty et al., 2019) and academic achievement (Burhanuddin et al., 2019). Psycap is a persons' psychological mechanism related to his capacity and psychological development to accomplish any certain task or solve a particular problem. Hence, PsyCap is related to positive psychology that encourages people to recognize the strengths that exist in themselves (Margiadi \& Wibowo, 2019). According to Luthans and Youssef-Morgan (2017), PsyCap refers to an individuals' positive and developmental state characterized by selfefficacy, optimism, hope, and resiliency. Self-efficacy is an individuals' belief in their capabilities to complete tasks. Optimism refers to the clear appraisal and judgment of current situations and understanding of what can do in such situations. Hope is related to an individuals' belief in their determination to achieve their goals and find possible pathways to overcome difficulties. Resilience is the ability to recover from adversity or setbacks, proactively rise to challenges, and adapt to an ever-changing business environment (Tang et al., 2019). The four indicators: self-efficacy, optimism, hope, and resilience, if in high conditions it has the potential to increase teachers' $O C B$, which is manifested in altruism, conscientiousness, sportsmanship, courtesy, and civic virtue. Scholars concluded (e.g., Aderibigbe \& Mjoli, 2018; Adillah et al., 2019; El-Zohiry \& Abd-Elbaqy, 2019; Yildiz, 2019; Kong et al., 2018; Nawaz \& Abid, 2019; Chamisa et al., 2020; Rodríguez-Cifuentes et al., 2020; Da et al., 2021) that PsyCap affects OCB. Therefore, can formulate the first hypotheses:

\section{$\mathrm{H}_{1}$ : PsyCap has a direct effect on OCB}

\subsection{Affective Commitment and OCB}

The study of organizational commitment, especially affective commitment, is always interesting and exciting for very rational reasons. Affective commitment has been shown to positively and significantly affect individual lives in various organizational contexts. For example, affective commitment can reduce burnout and intentions to leave (Enginyurt et al., 2016; DiPietro et al., 2020). Affective commitment is also related to proactive work behavior (Luu, 2017) and performance (Van Waeyenberg et al., 2020), including extra-role performance (Wang et al., 2020). Moreover, affective commitment significantly influences job satisfaction (Lambert et al., 2019; Loan, 2020) and work engagement Choi et al. (2015). In the marketings' study, affective commitment is related to customer orientation (Lombardi et al., 2019) and electronic word of mouth (Mohammed \& Al-Swidi, 2020). It confirms that affective commitment has an immense contribution to individuals and then has implications for the dynamics of organizational life. In the organizational context, commitment is the degree to which an employee identifies with the organization and wants to continue actively participating, willing to put forth effort on its behalf (Newstrom, 2016; Noe et al., 2019). Meanwhile, affective commitment refers to the employees' emotional attachment to organizational values - how much an employee likes the organization and reflects the quality of employee-organization exchange relationship (Wang et al., 2020). Affective commitment is also reflected in the positive emotions of employees to try and choose to remain part of the organization, such as feelings are identical to organizational goals, a feeling of being involved in organizational tasks, and feeling loyal to the organization (Newstrom, 2016; Ivancevich, Konopaske, \& Matteson, 2018). When a teacher has strong feelings towards organizational goals and is actively involved and loyal to the school organization, those feelings can increase in altruism, conscientiousness, sportsmanship, courtesy, and civic virtue of teachers as a manifestation of OCB. The researchers' studies also proved that affective commitment influences OCB (e.g., Perkasa et al., 2020; Kristian \& Ferijani, 2020). Therefore, can formulate the second hypothesis:

\section{$\mathrm{H}_{2}$ : Affective commitment has a direct effect on OCB.}

\subsection{Psycap and Affective Commitment}

Affective commitment reflected in feelings is identical to organizational goals; a feeling of being involved in organizational tasks and feeling loyal to the organization not only affects OCB but is also influenced by Psycap. Individuals who have high self-efficacy, optimism, hope, and resilience, a reflection of PsyCap, will tend to have strong feelings identical to organizational goals, a feeling of being involved in organizational tasks, and feeling loyal to the organization. The recent studies in various countries, fields, and contexts also prove that PsyCap has a significant effect on organizational commitment, including affective commitment (e.g., Huynh \& Hua, 2020; Surucu et al., 2020; Nguyen \& Ngo, 2020). Therefore, can formulate the third hypothesis:

$\mathrm{H}_{3}$ : PsyCap has a direct effect on affective commitment.

\subsection{Psycap and OCB Mediated by Affective Commitment}


Affective commitment also mediates the effect of PsyCap on OCB. The indicators of PsyCap, such as self-efficacy, optimism, hope, and resilience, if adequate potentially stimulates affective commitment reflected in feelings is identical to organizational goals; a feeling of being involved in organizational tasks and feeling loyal to the organization and then it implicates to OCB manifested in altruism, conscientiousness, sportsmanship, courtesy, and civic virtue. The recent previous studies also revealed that PsyCap affects affective commitment (e.g., Nangoy \& Hamsal, 2018; Tang et al., 2019), while several studies show that affective commitment is related to OCB (e.g., Cheasakul \& Varma, 2016; Harwiki, 2016;

Leephaijaroen, 2016; Sukrisnawati et al., 2019). However, no previous research has been found that specifically examines the effect of PsyCap on OCB mediated by affective commitment. There are similar studies, for example, the research of Gupta et al. (2017), who examined the influence of PsyCap on OCB mediated by work engagement, and the study of Paul et al. (2016) investigated the effect of employee resilience and OCB mediated by organizational commitment. It requires empirical confirmation that promises novelty. Based on the argument and studies above, can formulate the fourth hypothesis:

$\mathrm{H}_{4}$ : PsyCap has an indirect effect on OCB mediated by affective commitment.

\section{Methods}

This research uses a quantitative approach to the survey method through a Likert scale model questionnaire with five option answers: strongly disagree $($ score $=1)$, disagree $($ score $=2)$, neutral (score $=3$ ), agree $($ score $=4)$, and strongly agree $($ score $=5)$ to verify the hypotheses (Hair et al., 2018). This research took place during the Covid 19 pandemic, which requires everyone to comply with health protocols, especially social distancing, so the survey was conducted online using the google form format, which shares through the WhatsApp application on the teacher group WhatsApp network. The questionnaire was made by researchers based on the theoretical dimensions or indicators of the experts. The dimensions/indicators of PsyCap: self-efficacy, optimism, hope, and resiliency (Luthans \& Youssef-Morgan (2017). Affective commitment: feelings are identical to organizational goals, a feeling of being involved in organizational tasks, and feeling loyal to the organization (Newstrom, 2016; Ivancevich, Konopaske, \& Matteson, 2018). OCB: altruism, conscientiousness, sportsmanship, courtesy, and civic virtue (Organ et al., 2006). The questionnaire of PsyCap consists of 12 items (alpha coefficient $=.905$ ), affective commitment consists of 10 items (alpha coefficient $=.953$ ), and OCB consists of 10 items (alpha coefficient $=.863$. All variables have an alpha coefficient $>.7$, so it is reliable as a research instrument (Griethuijsen et al., 2014; Hair et al., 2019).

This research participant is 469 senior high school teachers in Indonesia spread across eight provinces (Jakarta, Banten, West Java, Central Java, Riau Islands, Lampung, East Kalimantan, and East Nusa Tenggara). The research participant was determined by accidental sampling based on participant willingness to fill in the questionnaire when the research was conducted (Widodo, 2019). As shown in Table 1, the majority of gender is female (68.66\%), ages 26 - 35 years (35.82\%), bachelor education (89.97\%), marital status $(79.11 \%)$, and length of teaching $\geq 16$ years $(30.27 \%)$.

Table 1. Profile of The Research Participant

\begin{tabular}{lll}
\hline Profile & Amount & Percentage \\
\hline Gender & & \\
1. Male & 147 & 31.34 \\
2. Female & 322 & 68.66 \\
Age & & \\
$1 . \quad 325$ years & 39 & 8.32 \\
2. 26-35 years & 168 & 35.82 \\
3. $\quad 36-45$ years & 114 & 24.30 \\
4. 46-55 years & 113 & 24.09 \\
5. $\geq 56$ years & 35 & 7.47 \\
Education & & \\
1. Diploma (D3) & 20 & 4.27 \\
2. Bachelor (S1) & 422 & 89.97 \\
3. Postgraduate (S2) & 27 & 5.75 \\
4. Doctoral (S3) & 0 & 0 \\
Status & & \\
1. Married & 371 & 79.11 \\
2. Unmarried & 98 & 20.89 \\
Length of Teaching & & \\
1. $\leq 5$ years & 135 & 28.79
\end{tabular}




\begin{tabular}{llll} 
2. & $6-10$ years & 90 & 19.18 \\
3. & $11-15$ years & 102 & 21.75 \\
4. & $\geq 16$ years & 142 & 30.27 \\
\hline
\end{tabular}

Data analysis uses path analysis, and to test its significance, uses a t-test supported by descriptive statistics and correlational. Path analysis was conducted with Lisrel 8.80, and then analysis descriptive and correlational by SPSS version 26.

\section{Result and Discussion}

The descriptive statistical analysis and correlations of the three research variables are present in Table 2 . The mean values of the three variables from the lowest to the highest in succession are OCB (41.30), affective commitment (41.62), and PsyCap (52.88). Meanwhile, the standard deviation values of the three variables from the lowest to the highest in succession are OCB (4.811), PsyCap (5.451), and affective commitment (5.915). In general, the standard deviation value is smaller than the mean values so that it reflects a good representation of the overall data. The correlation analysis results in all variables have significant relationships with the other variables at level $p<.01$. This condition indicates that all the variables have a mutual relationship with each other. The correlation coefficient from the lowest to the highest in succession are affective commitment and OCB (.369), PsyCap and affective commitment (.464), and PsyCap and OCB (.483).

Table 2. Descriptive Statistics and Correlation Matrix

\begin{tabular}{lcccc}
\hline Variables & Mean & Std. Deviation $\mathbf{1}$ & $\mathbf{2}$ & $\mathbf{3}$ \\
\hline 1. PsyCap & 52.88 & 5.451 & 1.00 & $.464^{* *}$ \\
2. Affective commitment & 41.62 & 5.915 & .00 & $.483^{* *}$ \\
3. OCB & 41.30 & 4.811 & $.369^{* *}$ & 1.00 \\
\hline
\end{tabular}

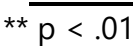

The hypothesis testing result with path analysis of PsyCap on OCB mediated by affective commitment is summarized in Table 3 and visualized in Figure 1 and Figure 2. As present in Table 3, all the hypotheses were supported, indicating $t$ value $>t$ table at $\alpha$ $=.01$ (1.96). That means that PsyCap significantly affects OCB, directly or indirectly mediated by affective commitment. In detail, the path coefficient a direct effect from the lowest to the highest in succession are an affective commitment on OCB (.18), PsyCap on OCB (.40), and Psycap on affective commitment $(=.46)$. It is indicated that the direct effect of PsyCap on affective commitment is better than others, including the indirect effect of PsyCap on OCB mediated by affective commitment.

Table 3. Summary of Path Coefficients and T values

\begin{tabular}{|c|c|c|c|}
\hline Hypothesis & $\begin{array}{l}\text { Path } \\
\text { Coefficients }\end{array}$ & $\begin{array}{l}\mathbf{T} \\
\text { Value }\end{array}$ & $\begin{array}{l}\text { Hypothesis } \\
\text { Testing }\end{array}$ \\
\hline $\mathrm{H}_{1}:$ Psycap $(\mathrm{X})$ on OCB $\left(\mathrm{Y}_{2}\right)$ & $.40^{\star \star}$ & 8.82 & Supported \\
\hline $\mathrm{H}_{2}$ : Affective commitment $\left(\mathrm{Y}_{1}\right)$ on OCB $\left(\mathrm{Y}_{2}\right)$ & $.18^{* *}$ & 4.09 & Supported \\
\hline $\mathrm{H}_{3}:$ Psycap $(X)$ on affective commitment $\left(\mathrm{Y}_{1}\right)$ & $.46^{* *}$ & 11.32 & Supported \\
\hline $\mathrm{H}_{4}$ : Psycap $(\mathrm{X})$ on OCB $\left(\mathrm{Y}_{2}\right)$ mediated by affective commitment $\left(\mathrm{Y}_{1}\right)$ & $.09 * *$ & 3.85 & Supported \\
\hline
\end{tabular}

$* \star p<.01$

As shown in Figures 1 and 2, the test results of the fittest of structural model show the significant with Chi-Square $=0.000, \mathrm{df}=0$, $\mathrm{p}$-value $=1.00000>.05$, and RMSEA $=.000<.08$, so that the model tested is fit. This result indicates that the theoretical model being tested is supported by empirical data from senior high school teachers in Indonesia. 


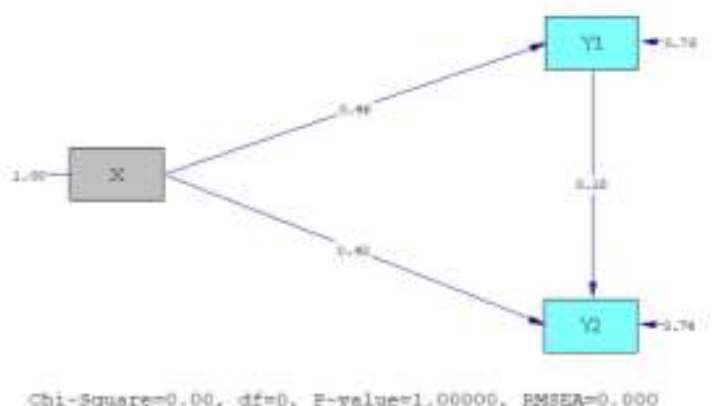

Figure 1. Path Coefficients

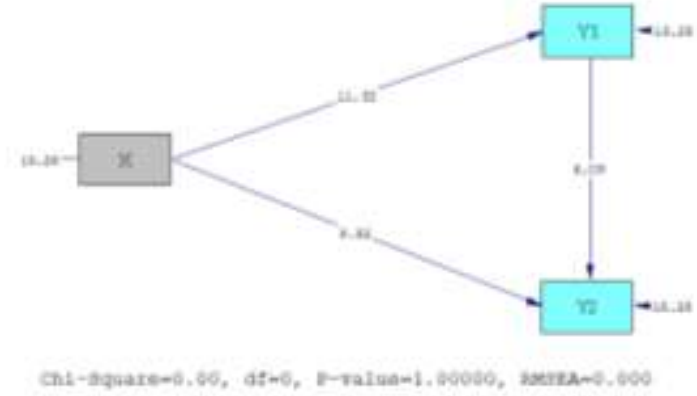

Figure 2. T Values

This research proved that PsyCap significantly affects $O C B$, directly or indirectly mediated by affective commitment. It shows three critical pieces of evidence. First is the vitality of PsyCap and affective commitment for teachers' OCB. That means the existence of PsyCap and affective commitment are essential determinants for enhancing teachers' OCB. This is similar and consistent with studies conducted by researchers that PsyCap influences OCB (Chamisa et al., 2020; Rodríguez-Cifuentes et al., 2020; Da et al., 2021), and affective commitment affects OCB (e.g., Perkasa et al., 2020; Kristian \& Ferijani, 2020). This empirical fact confirms that PsyCap and affective are vital for teachers' OCB, so that it needs to maintain, managed, and developed optimally. Consequently, school principals need to pay more attention to increasing teachers' PsyCap and affective commitment. In this context, school principals need to encourage schools to become learning organizations that allow teachers' Psycap and affective commitment to grow and even more fertile to improve teachers' OCB. These efforts should focus on seeding PsyCap: self-efficacy, optimism, hope, and resiliency (Luthans \& Youssef-Morgan (2017) and affective commitment: feelings are identical to organizational goals, a feeling of being involved in organizational tasks, and feeling loyal to the organization (Newstrom, 2016; Ivancevich, Konopaske, \& Matteson, 2018).

Second, the essentiality of PsyCap for teachers' affective commitment. It shows that PsyCap is not only important for teachers' OCB but also crucial for teachers' affective commitment. This finding aligns with previous studies that Psycap has a significant relationship with affective commitment (Surucu et al., 2020; Nguyen \& Ngo, 2020. This means that the improvement of PsyCap can also positively contribute to increasing teachers' affective commitment. For example, improving self-efficacy and resilience can increase teacher involvement in various school activities. Therefore, principals should not hesitate to build teacher PsyCap in various ways, formally such as training, workshops, counseling, or informally through inspirational and motivational efforts.

Finally, found the mediating effect of affective commitment for PsyCap on teachers' OCB. It shows the strategic position of affective commitment between Psycap and OCB. That means effective commitment is essential in the context of the relationship between PsyCap and OCB. In other words, affective commitment needs to consider in the context of efforts to increase OCB through PsyCap. This finding also aligns with previous studies that Psycap has a significant relationship with affective commitment (Surucu et al., 2020; Nguyen \& Ngo, 2020), and affective commitment affects OCB (e.g., Perkasa et al., 2020; Kristian \& Ferijani, 2020). Moreover, this evidence also confirms that affective commitment plays a significant role as a mediator of PsyCap on teachers' OCB. It is a novelty in the new research model regarding PsyCap affects teachers' OCB, mediated by affective commitment, supported by data on senior high school teachers in Indonesia. Therefore, affective commitment needs to consider enhancing teachers' OCB through PsyCap. Thus, the effort to enhance teachers' OCB will be better if improving PsyCap with support by affective commitment.

\section{Conclusion}

This study investigates the effect of PsyCap on OCB mediated by affective commitment. The result found that PsyCap and affective commitment significantly affect OCB. Affective commitment is also significantly influenced PsyCap. Besides, affective commitment is indirectly mediating the effect of PsyCap on teachers' OCB. Therefore, the new empirical model of PsyCap on OCB mediating by affective commitment was confirmed. This new model can discuss among researchers and practitioners to build OCBs' model that can adapt and adopt to improve OCB. Hence, the research suggested that the teachers' OCB can improve through PsyCap and affective commitment. For researchers, this new model can be applied to educational organizations (including school organizations) or other organizations (including business and public organizations) to develop and expand research more comprehensively by adding new dimensions/indicators or using analytical approaches, such as structural equation modeling (SEM) that processing using SmartPLS. Furthermore, researchers can also expand the research area, for example, by adding research participants from other provinces in Indonesia or other countries. For practitioners, a new model can be implemented to improve teachers' OCB by considering their PsyCap and affective commitment actual condition. However, this requires good faith and an innovative approach from school principals who are specifically scheduled to improve teacher OCB as capital to help students who face learning difficulties and achieve the best academic achievements, especially during the Covid-19 pandemic. School success in 
improving teacher $\mathrm{OCB}$ will have an impact on increasing student academic achievement, which then has implications for improving school organizational performance.

Funding: This research received no external funding.

Acknowledgments: We are very grateful to the teachers in Indonesia who volunteered to spend their time and full dedication to responding to every statement item in the questionnaire completely and perfectly so that it could be used as research material in this article. May this willingness and dedication be a contribution to the development of science that can seeding to civilization.

Conflicts of Interest: The authors declare no conflict of interest.

\section{References}

[1] Aderibigbe, J. K, \& Mjoli, T. Q. (2018). Evaluation of the components of psychological capital and organizational citizenship behavior among Nigerian graduate employees. Journal of Economics and Behavioral Studies 10: 38-50. https://doi.org/10.22610/jebs.v10i5(J).2496.

[2] Adillah, M. N., Sidin, I., \& Amqam. H. (2019). Impact of psychological capital on organizational citizenship behavior (OCB) towards male and female nurses in teaching hospital. Dama Academic Scholarly Journal of Researchers 4: 21-25. https://doi.org/10.15373/22501991.

[3] Ali, I., Khan, M. M., Shakeel, S., \& Mujtaba, B. G. (2021). Impact of psychological capital on the performance of public hospital nurses: The mediated role of job embeddedness. Public Organization Review, 1-20. https://doi.org/10.1007/s11115-021-00521-9.

[4] Alias, N. E., Abu, N., Koe, W-L., Marmaya, N. H., \& Romaiha, R. O. N. R. (2020). Does psychological capital matter for the public sector employees? A survey of the impact of psychological capital on individual job performance in Malaysia. International Journal Academic Research in Business and Social Sciences, 10(8), 772-787. https://doi.org/10.6007/IJARBSS/v10-i8/7625.

[5] Baluku, M. M., Mugabi, E. N., Nansamba, J., Matagi, L., Onderi, P., \& Otto, K. (2021). Psychological capital and career outcomes among final year university students: the mediating role of career engagement and perceived employability. International Journal of Applied Positive Psychology, 6, 55-80. https://doi.org/10.1007/s41042-020-00040-w

[6] Barsulai, S. C., Makopondo, R.O.B., \& E. V.O. Fwaya, E. V.O. (2019). The impact of organizational citizenship behavior on employee productivity in star-rated hotels in Kenya. European Journal of Hospitality and Tourism Research, 7(1), 1-8.

[7] Burhanuddin, N. A. N., Ahmad, N. A., Said, R. R., \& Asimiran, S. (2019). A Systematic Review of the Psychological Capital (PsyCap) Research Development: Implementation and Gaps. International Journal of Academic Research in Progressive Education and Development, 8(3), 133150. http://dx.doi.org/10.6007/IJARPED/v8-i3/6302

[8] Carmona-Halty, M., Schaufeli, W. B., \& Salanova, M. (2019). Good relationships, good performance: The mediating role of psychological capital - a three-wave study among students. Front. Psychol., 10(306), 1-5. https://doi: 10.3389/fpsyg.2019.00306.

[9] Chamisa, Shingirayi F., Temba Q. Mjoli, and Tatenda S. Mhlanga. (2020). Psychological capital and organizational citizenship behavior in selected public hospitals in the Eastern Cape Province of South Africa. SA Journal of Human Resource Management /SATydskrifvirMenslikehulpbronbestuur 18: a1247. https://doi.org/ 10.4102/sajhrm.v18i0.1247.

[10] Cheasakul. U., Varma, P. (2016). The influence of passion and empowerment on organizational citizenship behavior of teachers mediated by organizational commitment. Contaduría y Administración, 61, 422-440.

[11] Choi, S. B., Tran, T. B. H., Park, B. I. (2015). Inclusive leadership and work engagement: Mediating roles of affective organizational commitment and creativity. Social Behavior and Personality, 43(6), 931-944. http://dx.doi.org/10.2224/sbp.2015.43.6.931

[12] Da, S, Ze Z, Hongyu C, Xianmin G, Oi L S, \& Xichao Z. (2021). Psychological capital, positive affect, and organizational outcomes: a threewave cross-lagged study. Journal of Pacific Rim Psychology 15: 1-13. https://doi.org/10.1177/18344909211010514.

[13] DiPietro, R. B., Moreo, A., \& Cain, L. (2020). Well-being, affective commitment, and job satisfaction: Influences on turnover intentions in casual dining employees. Journal of Hospitality Marketing \& Management, 29(2), 139-163. https://doi.org/10.1080/ 19368623.2019.1605956

[14] El-Zohiry, Amira A., and Khadeeja Y. Abd-Elbaqy. (2019). The moderating effect of intrinsic motivation on the relationship between psychological capital and organizational citizenship behaviors. Management Review: An International Journal 14: 4-32.

[15] Enginyurt, O., Cankaya, S., Aksay, K., Tunc, T., Koc, B., Bas, O., \& Ozer, E. (2016). Relationship between organizational commitment and burnout syndrome: A canonical correlation approach. Australian Health Review, 40, 181-187. http://dx.doi.org/10.1071/AH14177.

[16] Gupta, M., Shaheen, M., \& Reddy, P. K. (2017). Impact of psychological capital on organizational citizenship behavior: Mediation by work engagement. Journal of Management Development, 36 (7), 973-983, https://doi.org/10.1108/JMD-06-2016-0084.

[17] Gustari, I., \& Widodo, W. (2020). The power of lecturer's organizational commitment in Indonesian private higher education. International Journal of Innovation, Creativity, and Change, 14(8), 262-277.

[18] Hair, J. F., Babin, B. J., Anderson, R. E., \& Black, W. C. (2019). Multivariate data analysis (8th ed.). India: Cengage India.

[19] Harwiki, W. (2016). The impact of servant leadership on organization culture, organizational commitment, organizational citizenship behavior (OCB), and employee performance in women cooperatives. Procedia-Social and Behavioral Sciences, 219, 283-290.

[20] Hermawan, H., Thamrin, H. M., \& Susilo, P. (2020). Organizational citizenship behavior and performance: the role of employee engagement. Journal of Asian Finance, Economics, and Business, 7(12), 1089-1097. https://doi:10.13106/jafeb.2020.vol7.no12.1089.

[21] Huynh, T. N., \& Hua, N. T. A. (2020). The relationship between task-oriented leadership style, psychological capital, job satisfaction, and organizational commitment: evidence from Vietnamese small and medium-sized enterprises. Journal of Advances in Management Research. https://doi:10.1108/jamr-03-2020-0036

[22] Imran, M., \& Shahnawaz, M. G. (2020). PsyCap and performance: wellbeing at work as a mediator. Asia-Pacific Journal of Management Research and Innovation, 1-10. https://doi.org/10.1177/2319510X20915999.

[23] Ivancevich, J. M., Konopaske, R., \& Matteson, M. T. (2018). Organizational behavior and management (11 ${ }^{\text {th }}$ ed.). New York: McGraw Hill Company. 
[24] Kong, Fanzhu, Cheng-Hung Tsai, Fu-Sheng Tsai, Wenti Huang, and Shareena Malapitan de la Cruz. (2018). Psychological capital research: A meta-analysis and implications for management sustainability. Sustainability 10: 1-9. https://doi.org/10.3390/su10103457.

[25] Kristian, B., \& Ferijani, V. (2020). The effect of job satisfaction and organizational commitment on employee performance with OCB as the intervening variables. Journal of Management and Business Environment, 2, (1), 21-28.

[26] Lambert, E. G., Keena, L. D., Leone, M., May, D., \& Haynes, S. H. (2019). The effects of distributive and procedural justice on job satisfaction and organizational commitment of correctional staff. The Social Science Journal, 1-9. https://doi.org/10.1016/ j.soscij.2019.02.002

[27] Leephaijaroen, S. (2016). Effects of the big-five personality traits and organizational commitments on organizational citizenship behavior of support staff at Ubon Ratchathani Rajabhat University, Thailand. Kasetsart Journal of Social Sciences, 37, 104-111.

[28] Loan, L. T. M. (2020). The influence of organizational commitment on employees' job performance: The mediating role of job satisfaction. Management Science Letters, 10, 3307-3312. https://doi: 10.5267/j.msl.2020.6.007

[29] Lombardi, S., Sassetti, S., \& Cavaliere, V. (2019. Linking employees' affective commitment and knowledge sharing for increased customer orientation. International Journal of Contemporary Hospitality Management, 31(11), 4293-4312. https://doi.org/10.1108/ IJCHM-03-2018$\underline{0261}$

[30] Luthans, F., \& Youssef-Morgan, C. M. (2017). Psychological capital: An evidence-based positive approach. Reviews in Advance, 4, $339-366$. https://doi.org/10.1146/annurev-orgpsych-032516-113324

[31] Luu, T. (2017). Discretionary HR practices and proactive work behavior: The mediation role of affective commitment and the moderation roles of PSM and abusive supervision. Public Management Review, 1-36. https://doi: 10.1080/14719037.2017. 1335342

[32] Margiadi, B., \& Wibowo, A. (2019). A bibliometric review of psychological capital. International conference on rural development and entrepreneurship 2019: Enhancing small business and rural development toward industrial revolution 4.0. 5 (1), 993-1004.

[33] McShane, S. L., \& Von Glinow, M. A. (2020). Organizational behavior: Emerging knowledge, global reality. 9th edition. United States: McGrawHill Education.

[34] Mohammed, A., \& Al-Swidi, A. (2020): The mediating role of affective commitment between corporate social responsibility and eWOM in the hospitality industry. Journal of Sustainable Tourism. https://doi: 10.1080/09669582.2020.1818086.

[35] Nangoy, R., \& Hamsal, M. (2018). An interaction between employee psychological capital perceived organizational fit, and work well-being on organizational commitment: an empirical study on e-commerce industry in Indonesia. Journal of Strategic and Global Studies, 1(1), 25-46. https://doi: 10.7454/jsgs.v1i1.1002

[36] Nawaz, M., \& Abid, G. (2019). Do prosocial motivation and psychological capital improve organizational citizenship behavior? An empirical study through the moderating role of workplace incivility. Journal Research Square: 1-23. https://doi.org/10.21203/rs.2.10794/v1.

[37] Newstrom, J. W. (2016). Organizational behavior: Human behavior at work (12 ${ }^{\text {th }}$ ed.). Boston: Tata McGraw-Hill.

[38] Nguyen, H. A., \& Ngo, T. T. (2020). Psychological capital, organizational commitment, and job performance: A case in Vietnam. Journal of Asian Finance, Economics, and Business, 7(5), 269 - 278. https://doi:10.13106/jafeb.2020.vol7.no5.269.

[39] Noe, R. A., Hollenbeck, J. R., Gerhart, B., \& Wright, P. M. (2019). Human resource management: Gaining a competitive advantage (11 ed.). New York: McGraw-Hill Education.

[40] Notanubun, Z. (2020). The effect of organizational citizenship behavior and leadership effectiveness on public sectors organizational performance: Study in the Department of Education, Youth and Sports in Maluku Province, Indonesia. Public Organization Review, 1-18. https: //doi:10.1007/s11115-020-00475-4

[41] Organ, D. W., Podsakoff, P. M., \&MacKenzie, S. B. (2016) Organizational citizenship behavior: Its nature, antecedents, and consequences. California: Sage Publications, Inc.,

[42] Paul, H., Bamel, U. K., \& Garg, P. (2016). Employee Resilience and OCB: Mediating Effects of Organizational Commitment. Vikalpa, 41(4), 308324. doi:10.1177/0256090916672765

[43] Perkasa, D. H., Abadi, F., \& Shandy, D. F. A. (2020). The effect of emotional intelligence, servant leadership, and organizational commitment on organizational citizenship behavior; A study of the South Tangerang City Education and Culture Office. Advances in Economics, Business and Management Research, 120, 97-102, 2020.

[44] Rodrigues, R. I., Carochinho, B. J.-A., \& Rendeiro, O. M. M. (2017). the Impact of Positive Psychological Capital on the Psychological Distress of Primary and Secondary Education Teachers. Psique, Journal of Research Centre for Psychology of the Universidade Autonoma de Lisboa, 12, 40-56.

[45] Rodríguez-Cifuentes, F., Segura-Camacho, A., García-Ael, C., \& Topa, G. (2020). The mediating role of psychological capital between motivational orientations and their organizational consequences. International Journal of Environmental Research and Public Health, 17(13), 1-20. https://doi.org/10.3390/ijerph17134864.

[46] Schultz, D., \& Schultz, S. E. (2016). Psychology and work today. New Jersey: Routledge.

[47] Slatten, T., Mutonyi, B. R., \& Lien, G. (2020). The impact of individual creativity, psychological capital, and leadership autonomy support on hospital employees' innovative behavior. BMC Health Services Research, 20(1096), 1-17. https://doi.org/10.1186/s12913-020-05954-4

[48] Sukrisnawati, G. A., Agung, A. A. P., \&Sudja, I. N. (2019). The effect of leadership and organization commitments to performance of contract employees with organizational citizenship behavior $(\mathrm{OCB})$ as a mediation variable (Study at Abiansemal I Health Center and Abiansemal II). IJSEGCE, 2 (3), 310-319.

[49] Surucu, L., Maşlakcı, A., \& Şeşen, H. (2020). The role of positive psychological capital in the effect of leadership styles on organizational commitment: A study of hospitality services. African Journal of Hospitality, Tourism and Leisure, 9(2), 1-16.

[50] Tang, Y., Shao, Y-F., \& Chen, Y-J. (2019). Assessing the mediation mechanism of job satisfaction and organizational commitment on innovative behavior: The perspective of psychological capital. Front. Psychol., 10, 1-12. https://doi: 10.3389/fpsyg.2019.02699.

[51] Udin, U., \& Yuniawan, A. (2020). Psychological capital, personality traits of big-five, organizational citizenship behavior, and task performance: Testing their relationships. Journal of Asian Finance, Economics, and Business, 7(9), 781790. https://doi.org/10.13106/jafeb.2020. vol7.no9.781 
[52] Van Griethuijsen, R. A. L. F., van Eijck, M. W., Haste, H., den Brok, P. J., Skinner, N. C., Mansour, N., Gencer, A. S., \& BouJaoude, A. (2014). Global patterns in students' views of science and interest in science. Research in Science Education, 45(4), 581-603. https://doi.org/10.1007/s11165-014-9438-6.

[53] Van Waeyenberg, T., Peccei, R., \& Decramer, A. (2020). Performance management and teacher performance: the role of affective organizational commitment and exhaustion. The International Journal of Human Resource Management, 1-24. https:// doi:10.1080/09585192.2020.1754881

[54] Wang, H., Han, X., \& Li, J. (2020). Supervisor narcissism and employee performance: A moderated mediation model of affective organizational commitment and power distance orientation. Basic and Applied Social Psychology, 1-17. https://doi.org/10.1080/01973533.2020.1810042

[55] Wang, Y., Chen, Y., \& Zhu, Y. (2021). Promoting innovative behavior in employees: The mechanism of leader psychological capital. Front. Psychol., 11:598090. https://doi: 10.3389/fpsyg.2020.598090

[56] Widodo, W. (2019). Popular \& practical research methodologies (in Indonesia). Depok: Rajawali Pers.

[57] Widodo, W., \& Gustari, I. (2020). Teachers' innovative behavior in Indonesian school: The role of knowledge management, creativity, and OCB. Universal Journal of Educational Research, 8 (10), 4784-4791.

[58] Yildiz, H. (2019). The interactive effect of positive psychological capital and organizational trust on organizational citizenship behavior. SAGE Open: 1 -15. https://doi.org/10.1177/2158244019862661. 